\title{
About uses of magnesium during perioperative period
}

\author{
Jeong Uk Han \\ Department of Anesthesiology and Pain Medcine, Inha University Hospital, Incheon, Korea
}

Magnesium (Mg) is an essential mineral needed for cell function, and the necessary amount required by the body is obtained through consumption of food and mineral water. Leafy vegetables, grains, and legumes, which are a staple of Asians diets, have abundant $\mathrm{Mg}$, while the dairy products of nomads or diets using meat of Western society lack ample consumption of this mineral [1]. As a result, there are assertions that those in the Western population are more likely to develop cardiovascular or hyperlipidemic diseases [2]. Recently, Mg-abundant foods and a daily intake of $\mathrm{Mg}$ have been recommended to forge improved public health [3].

It is difficult to identify cases of Mg deficiency. A long halflife period (radio-labeled Mg half life; $41-181 \mathrm{~d}$ ) is required to equalize its concentration in the body tissues [4], and while it is mostly present in intracellular compartment of bones, muscles, and soft tissues, the concentration of $\mathrm{Mg}$ is merely $1 \%$ in extracellular fluids and $0.3 \%$ in plasma. As a result, it is difficult to make a diagnosis of hypomagnesemia on the grounds that the concentrations of $\mathrm{Mg}$ are less than the normal concentrations of the total plasma magnesium ranging from 0.7 to $1.0 \mathrm{mM}(1.7-2.5 \mathrm{mg} / \mathrm{dl})$ [5]. A Mg retention test or loading test, which evaluates the excreted amount of $\mathrm{Mg}$ after an injection of the mineral, is used to make an accurate diagnosis, however the time required to obtain test results is longer than desired [6].

$\mathrm{Mg}$ reportedly blocks, reduces, or enhances the flow of ions by controlling several ion channels in the cell membrane [7], and it is involved in cell division, metabolism, and genetic expression by the activation of sub-cellular enzymes triggered by phosphorylated energy transfer through formation of ATP$\mathrm{Mg}$ complexes which anchor substrates to the active sites of enzymes [8]. In addition, it acts as an anticonvulsant by blocking the N-methyl-D-aspartate (NMDA) glutamate receptors, which is one of the excitatory aminoacid receptors [5]. And, the release of acetylcholine from the pre-synaptic endings is reduced by $\mathrm{Mg}$, where it mainly inhibits the entry of calcium into the presynaptic endings, playing an antagonistic role against calcium [9]. The vasodilatory effect, antiadrenergic action affecting on adrenal medulla and sympathetic nerve ending, and antiarrythmic effect of $\mathrm{Mg}$ indicates that it could be used for hypertension, pheochromocytoma, and sudden increase of blood pressure and heart rate during intubation [10,11].

Clinically, Mg replacement therapy is expected to be effective when it is deficient. However, unexpectedly, $7-11 \%$ of hospitalized patients and $40 \%$ of patients with deficiencies in other electrolytes and $65 \%$ of the clinically-ill patients in Intensive Care Unit have coexisting hypomagnesaemia [12-14]. Even so, it is difficult to find appropriate cases to provide a definitive indication for the administration of $\mathrm{Mg}$, which can lead to controversy over the argument that mortality would be reduced with normalization of plasma Mg concentration [15].

In cases of anesthesia, temporary Mg deficiency may occur in patients who are vulnerable to excessive expansion of extracellular fluid or who receive large volume of blood transfusions. In addition, patients who take diabetic medication, diuretics, parathyroid hormone after receiving thyroidectomy, angiotensin converting enzyme inhibitors for hypertension, laxatives for abdominal surgeries, and patients who have received bowel preparation for major intestinal resection are also at risk [5]. Mg administration is a well-known treatment for preeclampsia and eclampsia, and is also effective in torsades de pointes, when routine anti-arrhythmic treatment is refractory

Corresponding author: Jeong Uk Han, M.D., Department of Anesthesiology and Pain Medcine, Inha University Hospital, 7-206, Sinheung-dong 3-ga, Jung-gu, Incheon 400-711, Korea. Tel: 82-32-890-3968, Fax: 82-32-881-2476, E-mail: jwhanan@nate.com

(c) This is an open-access article distributed under the terms of the Creative Commons Attribution Non-Commercial License (http:// creativecommons.org/licenses/by-nc/3.0/), which permits unrestricted non-commercial use, distribution, and reproduction in any medium, provided the original work is properly cited. 
$[5,10,16]$. Recently, Mg has been reported as having analgesic effects in postoperative pain control, and attracting more attention [17]. But, there are many controversies over its efficacy because of many different variables impossible to compare in clinical tirals or reviews [18].

In general, Mg supplements is orally administered in healthy person with mild hypomagnesemia, but in cases of emergencies such as in eclampsia or arrhythmia or in treatments for severely-ill patients, resulting from severe Mg deficiency, which require IV injections of Mg. Infusion speed is important when $\mathrm{Mg}$ is intravenously injected. Deep tendon reflexes and the muscle contracting power begin to reduce when the blood concentration rises above normal value [19], and artificial ventilation is sometimes required due to dyspnea and unconsciousness if the concentration is too high [20]. Although $\mathrm{Mg}$ sulfate is commonly used intravenously, $\mathrm{Mg}$ chloride can be used in replacement therapy of Mg deficiency among Mg salts, and reportedly, more useful than Mg sulfate in absorption and retension [21]. The main differences between Mg sulfate and $\mathrm{Mg}$ chloride are anions which decide the biological properties and the interaction with water, do not make any reason to prefer Mg sulfate over Mg chloride [22].

There are diverse interactions between muscle relaxants and $\mathrm{Mg}$ according to the blocking mechanism of depolarizing or non-depolarizing muscle relaxants. Mg prevents muscular fasciculations and reduces the release of potassium outside the cell induced by succinylcholine injection, but it does not affect its onset and duration [23,24]. Mg affects the presynaptic membrane more than the post-synaptic membrane in enhancing blocking effect of non-depolarizing muscle relaxants [25]. Onset time was shortened and recovery time was prolonged when vecuronium-induced block was potentiated by $\mathrm{Mg}$ [26].

This month, a report by Kim et al. [27] stated that the onset of cis-atracurium was meaningfully shortened, but the duration had no significant differences when Mg was pre-injected before the injection of cis-atracurium. In particular, the reasons why a shortened onset and no significant differences in duration were found were assumed to be due to a small dose of $\mathrm{Mg}$ being given and the blood flow around the neuromuscular junction increasing at an initial stage, specifically when hemodynamic change occurred. It is interesting that $\mathrm{Mg}$ could be used under emergency circumstances including rapid sequence inductions, where activities require a short onset. However, it is necessary to investigate whether small dose of $\mathrm{Mg}$ will be influent on the other nondepolarizing muscle relaxants or not.

Research that investigates the efficacy of Mg in anesthesiology is currently growing, but they are structured mostly in animal testing or in vitro testing. Therefore, the value of perioperative use of $\mathrm{Mg}$ has not been estimated completely when considering its use for the human body. However, we are certain that its mechanism will be more clearly revealed in the near future and will be used effectively in the perioperative period.

\section{References}

1. Elin RJ. Magnesium metabolism in health and disease. Dis Mon 1988; 34: 161-218.

2. Ford ES, Mokdad AH. Dietary magnesium intake in a national sample of US adults. J Nutr 2003; 133: 2879-82.

3. Ketteler M, Jahnen-Dechent W. Magnesium basics. Clin Kidney J 2012; 5 (Suppl 1): i3-14.

4. Elin RJ. Magnesium: the fifth but forgotten electrolyte. Am J Clin Pathol 1994; 102: 616-22.

5. Herroeder S, Schönherr ME, De Hert SG, Hollmann MW. Magnesium--essentials for anesthesiologists. Anesthesiology 2011; 114: 971-93.

6. Cohen L, Laor A. Correlation between bone magnesium concentration and magnesium retention in the intravenous magnesium load test. Magnes Res 1990; 3: 271-4.

7. Guiet-Bara A, Durlach J, Bara M. Magnesium ions and ionic channels: activation, inhibition or block--a hypothesis. Magnes Res 2007; 20: $100-6$.

8. Killilea DW, Maier JA. A connection between magnesium deficiency and aging: new insights from cellular studies. Magnes Res 2008; 21: 77-82.

9. Jenkinson DH. The nature of the antagonism between calcium and magnesium ions at the neuromuscular junction. J Physiol 1957; 138: 434-44.

10. Fawcett WJ, Haxby EJ, Male DA. Magnesium: physiology and pharmacology. Br J Anaesth 1999; 83: 302-20.

11. Shimosawa T, Takano K, Ando K, Fujita T. Magnesium inhibits norepinephrine release by blocking N-type calcium channels at peripheral sympathetic nerve endings. Hypertension 2004 ; 44: 897 902.

12. Rubeiz GJ, Thill-Baharozian M, Hardie D, Carlson RW. Association of hypomagnesemia and mortality in acutely ill medical patients. Crit Care Med 1993; 21: 203-9.

13. Whang R, Oei TO, Aikawa JK, Watanabe A, Vannatta J, Fryer A, et al. Predictors of clinical hypomagnesemia. Hypokalemia, hypophosphatemia, hyponatremia, and hypocalcemia. Arch Intern Med 1984; 144: 1794-6.

14. Chernow B, Bamberger S, Stoiko M, Vadnais M, Mills S, Hoellerich V, et al. Hypomagnesemia in patients in postoperative intensive care. Chest 1989; 95: 391-7.

15. Huijgen HJ, Soesan M, Sanders R, Mairuhu WM, Kesecioglu J, Sanders GT. Magnesium levels in critically ill patients. What should we measure? Am J Clin Pathol 2000; 114: 688-95.

16. Ho KM. Intravenous magnesium for cardiac arrhythmias: jack of all trades. Magnes Res 2008; 21: 65-8.

17. Kroin JS, McCarthy RJ, Von Roenn N, Schwab B, Tuman KJ, Ivankovich AD. Magnesium sulfate potentiates morphine antinociception at the spinal level. Anesth Analg 2000; 90: 913-7.

18. Lysakowski C, Dumont L, Czarnetzki C, Tramer MR. Magnesium as an adjuvant to postoperative analgesia. A systematic review of randomized trials. Anesth Analg 2007; 104: 1532-9. 
19. Touyz RM. Magnesium in clinical medicine. Front Biosci 2004; 9: 1278-93.

20. Nassar AH, Sakhel K, Maarouf H, Naassan GR, Usta IM. Adverse maternal and neonatal outcome of prolonged course of magnesium sulfate tocolysis. Acta Obstet Gynecol Scand 2006; 85: 1099-103.

21. Durlach J, Bara M, Theophanides T. A hint on pharmacological and toxicological differences between magnesium chloride and magnesium sulphate, or of scallops and men. Magnes Res 1996; 9: 217-9.

22. Durlach J, Guiet-Bara A, Pagès N, Bac P, Bara M. Magnesium chloride or magnesium sulfate: a genuine question. Magnes Res 2005; 18: 187 92.

23. James MF, Cork RC, Dennett JE. Succinylcholine pretreatment with magnesium sulfate. Anesth Analg 1986; 65: 373-6.

24. Schreiber JU, Lysakowski C, Fuchs-Buder T, Tramer MR. Prevention of succinylcholine-induced fasciculation and myalgia: a metaanalysis of randomized trials. Anesthesiology 2005; 103: 877-84.

25. Lee C, Zhang X, Kwan WF. Electromyographic and mechanographic chararcteristics of neuromuscular block by magnesium sulphate in the pig. Br J Anaesth 1996; 76: 278-83.

26. Fuchs-Buder T, Wilder-Smith OH, Borgeat A, Tassonyi E. Interaction of magnesium sulphate with vecuronium-induced neuromuscular block. Br J Anaesth 1995; 74: 405-9.

27. Kim SH, So KY, Jung KT. Effect of magnesium sulfate pretreatment on onset and recovery characteristics of cisatracurium. Korean J Anesthesiol 2012: 62: 518-23. 